\title{
La invención de la tradición: leyendas apócrifas sobre los judíos de Hervás
}

The Invention of Tradition (La invención de la tradición) es el título de una colección, ya clásica, de estudios, reunidos por Eric Hobsbawn y Terence Ranger ${ }^{1}$ sobre los procesos de falsificación de la tradición histórico-cultural de muchos pueblos por espíritus o corrientes de opinión más o menos cultos e ilustrados, o simplemente interesados por razones politicas o económicas en moldear a su gusto o conveniencia la percepción del pasado y las tradiciones de sus pueblos. A la abundancia de datos que da esa obra clásica se ha añadido con los años una copiosa bibliografía que nos muestra, por ejemplo, cómo las "danzas nacionales" griegas son hábiles falsificaciones casi recientes a las que se ha dado una evidente rentabilidad política nacionalista ${ }^{2}$, o cómo, en la misma región extremeña que va a centrar nuestro estudio, la famosa gorra de Montehermoso es otra "tradición inventada" a la que también se le están sacando beneficios "de imagen" muy rentables, aunque acaso poco respetuosos con la esencia cultural más profunda de ese pueblo ${ }^{3}$.

Cuando en 1987 inicié mi trabajo de investigación sobre la historia de los judíos y conversos de Hervás, partí mayormente de una "tradición" oral que decía remontarse a tiempos inmemoriales y de abundantes artículos y crónicas periodísticas que a veces hasta ilustraban con fotografías los rincones más pintorescos de la «judería" hervasense. Después de ocho años de trabajo de documentación en más de veinte archivos y de pesquisas en una amplia bibliografía de hebraica, llegué a la conclusión de que las leyendas judeohervasenses surgieron en las postrimerías del siglo XIX, sobre una serie de infundios ahistóricos, alumbrados por ciertos eruditos locales y en buena medida asumidos y amplificados por la inventiva po-

1 La última reedición de la que tengo noticia es la de Cambridge, 1993.

2 Véase Lisbet TORP, "It's All Greek to me': the Invention of Pan-Hellenic Dances and Other National Stories", Telling Reality: Folklore Studies in Memory of Bengt Holbek, ed. Michael Chesmitt (Copenhague-Turku, 1993), pp. 273-294.

3 J. M VALADÉS SIERRA, aLa indumentaria como símbolo regional. La tradición inventada en el caso del traje femenino de Montehermoso", RDTP, XLIX (1994), pp. 91-117. 
pular, con lo que se fraguaron unas fingidas señas de identidad asociadas a un pasado judío que existió, pero que fue muy distinto - mucho más modesto y menos romántico- que el que nos pinta la pseudomitología moderna.

\section{FALSIFICACIONES PSEUDO-ERUDITAS LOCALES Y LEGITIMACIÓN INSTITUCIONAL}

La escasa pero valiosa documentación existente en el Archivo Histórico Nacional relativa a la vida de los judíos de Hervás no alude a ninguna judería como entidad urbanística o jurídica definida. Las escrituras registran viñedos judíos situados en las mejores zonas de cultivo del pueblo, casas abandonadas por los judíos en 1492, la sinagoga de rabí Simuel y la casa de la cofradía judeoconversa con su bodega, pilones de vino y cubas, granero y zarzo o secadero de productos agrícolas en la calle de la Amistad Judeo-Cristiana núm. $15^{4}$. La historiografía de los siglos XVIII y XIX desconoce igualmente la existencia del "barrio hebreo". Según las crónicas de A. Ponz, del hervasense Pedro de Aguilar y del italiano A. Conca ${ }^{5}$, los principales focos de interés artístico - hoy diríamos turístico- de Hervás eran en aquellos tiempos el convento de los religiosos trinitarios, la enfermería de los padres franciscanos - hoy sede del Ayuntamiento-, la iglesia parroquial de Santa María y la fábrica de tejidos del mercader Juan López. Tampoco hallamos referencia hebraica en las descripciones de A. Laborde, de la Sociedad de Literatos, de N. Díaz y Pérez, de P. Riera Sanz y de J. Mariana y Sanz ${ }^{6}$. Sólo a fines del siglo XIX asoman las primeras invenciones sobre el pasado judío de Hervás, tan influyentes y efectivas que en los últimos cien años mucha gente del pueblo y de fuera ha creído a pies juntillas en la importancia histórica del "barrio hebreo", considerando indiscutible su realidad histórica y llegándose in-

4 M. DE HeRvás, "Los judíos de Hervás", Carta de Jerusalén, XII, núm. 66 (Jerusalen, 1995), pp. 58-70.

5 A. PONZ, Viaje por España (Madrid, 1784), VII, 2. ${ }^{a}$ edición, p. 5; [P. DE AGUILAR], La provincia de Extremadura al final del s. XVIII (Mérida, 1991), pp. 238-240; y A. CoNCA, Descrizione odeporica della Spagna (Parma, 1795), p. 49.

6 A. LABORDE, Itinerario descriptivo de España (Valencia, 1826), p. 121; SOCIEDAD DE LITERATOS, Diccionario geográfico universal (Barcelona, 1831), IV, p. 505; N. DÍAZ Y PÉrez, Baños de Baños (Madrid, 1880), pp. 147-149; P. RIERA Y SANZ, Diccionario Geográfico, estadístico, bistórico, biográfico, postal, municipal, militar, marítimo y eclesiástico de España y sus posesiones de Ultramar (Barcelona, 1883), pp. 449-451; J. MARIANA Y SANZ, Diccionario geográfico, estadístico, municipal de España (Valencia, 1886), p. 284. 
cluso a presumir que es uno de los mejores conservados del país y de Europa ${ }^{7}$. ¿Qué ha sucedido para que una barriada no muy bien documentada en los textos y en la historiografía antigua haya cobrado repentina entidad mítica y "urbanística" en tiempos recientes? La carrera de equívocos comenzó cuando el maestro de escuela primaria A. Manzano Calzado, que no era nativo del lugar, sembró la primera semilla fabulesca en su artículo "Hervás y sus alrededores", fechado el 12 de agosto de 1886 y publicado 20 años después. Las teorías de A. Manzano sobre la judería hervasense se asientan sobre las difusas consideraciones de que una "calle de la población antigua conserva el nombre de calle de la Sinagoga, lo que prueba que en ella habría un templo judaico [...] debiendo ser en gran número a juzgar por el dicho antiguo que aún se conserva: 'en Hervás, judíos los más'" ${ }^{8}$. Estas apreciaciones fueron asumidas por el arquitecto V. Paredes en 1907: «estuve en el barrio del Ravilero y en la calle de la Sinagoga, cuyos nombres indican que pertenecía este bar[r]rio a los judíos" ${ }^{9}$; y entusiásticamente ampliadas por J. R. Mélida en 1924, al señalar que el barrio hebreo

se halla situado en una depresión del terreno a la parte NE. de la población y es sumamente curioso y pintoresco por las numerosas casas que conserva, típicas de la Edad Media, por lo general de dos pisos, el superior en saledizo y saliente también el alero del tejado; los muros de tierra apisonada, a veces resguardadas con tejas. Son curiosas las calles del Rabilero y la de la Sinoga, nombres en que fácilmente se adivina corrupción de términos tan significativos como Rabino... y Sinagoga ${ }^{10}$.

Los seguidores de Mélida se multiplicaron como los panes y los peces, divulgando una imagen cada vez más romántica y ficticia del «barrio hebraico" ${ }^{11}$. La confusión llegó hasta el extremo de que, como España aún

7 Sánchez Manzano, "Hervás, un privilegio", Hoy (Badajoz, 5 de enero de 1992), p. 27; F. Fidalgo, "Hervás", El País Semanal (Madrid, 9 de febrero de 1992), p. 90; E. BASTIDA, "Hervás", Guía del Ocio de Madrid (Madrid, 11 de julio de 1995), p. 38; S. SANTOS GonZálEz, "Hervás, integrada en los "Caminos de Sefarad", Hoy (Badajoz, 18 de febrero de 1995), p. 27; reproducido en Ferias y Fiestas de Hervás (1995) [p. 12-13]; L. MEDINA GARCíA, "Hervás, monumento a la tradicionalidad judía", España desconocida, núm. 4 (noviembre de 1995), pp. 28-41, p. 31; [artículo sin firmar] Hoy (Badajoz, 12 de marzo de 1997), p. 38.

8 V. PAREDES, “Hervás”, Revista de Extremadura, IX (1907), pp. 97-106, p. 99.

9 Ibidem, p. 105.

10 J. R. MÉlIDA, Catálogo monumental de España. Provincia de Cáceres. 1914-1916 (Madrid, 1924), II, p. 235.

11 La mayoría de las fábulas judaicas de Hervás fueron difundidas en la revista municipal de Ferias y Fiestas, nacida en 1947 y que todavía no ha homologado su 
no había entablado relaciones diplomáticas con Israel, el periódico Arri$b a$, órgano del Movimiento Nacional, publicó en 1972 el reportaje "Hervás, Palestina en la Alta Extremadura" ${ }^{12}$. En la estela de la promoción del turismo español que llevó a cabo en la década de 1960-1970 el ministro de Información y Turismo M. Fraga Iribarne, el Ayuntamiento franquista acordó promocionar la ajudería", y en los plenos de sesiones de 29 de julio y 26 de agosto de 1966, el concejo inició los trámites para declarar al "barrio judío" conjunto histórico-artístico. Previamente, la corporación municipal elaboró un mapa urbano señalando con una trama rayada el callejero "hebraico", que comprendía el puente "romano" —que no es romano sino del s. XVI- y las calles Abajo, Bodeguilla, Cuesta, Cuestecilla, Hospital, Rincón de Don Benito, Moral y Travesía, Rabilero y Travesía, Sinagoga y Vado. También añadieron al dossier "histórico" los postulados de J. Rodríguez Trinidad — del que trataremos más adelante- y el emblemático texto de Mélida:

Barrio judío.-De época medieval [...] se halla situado en la parte baja del pueblo, a orillas del río Ambroz [...] El barrio ha sufrido escasísimas modificaciones, siguen con sus nombres las calles de la Sinagoga, en la que estaba su templo, y la del Rabilero, donde vivió el Rabino. Al decretarse la expulsión de los judíos, vivía en Hervás un número considerable de los mismos, cuyos descendientes ahora son conocidos por su importancia en la esfera de los negocios, como los hermanos Cohen, Salvadiel, Moze Zarco, Jacob Cohen, Calama el Luengo, Haben Hazix, Rabí Samuel, Lombroso, Bellida la Rica, etc, que ejer-

mancheta. He optado por la denominación Ferias y Fiestas de Hervás [=FFH], que es la más utilizada. A. SÁNCHEZ HeRrero, "Si a la Feria vienes...", FFH (1947) [pp. 13-14, p. 14]; J. SÁNCHeZ MATAS, "Antiguas construcciones de Hervás", FFH (1948) [pp. 7-9, p. 7]; y "Datos interesantes de la historia de Hervás", $F F H$ (1960), pp. 23-29, p. 27; A. BASTOS BlÁZQUeZ, "Encuesta municipalista”, $F F H$ (1952), pp. 57-58, p. 57; V. GutiérReZ MACíAs, "La Leal e ilustre villa de Hervás", $F F H$ (1954), pp. 22-26, p. 26; conferencia pronunciada por el autor en Hervás, "Tesoro artístico de la provincian, el 25 de febrero de 1954; J. JimÉNEZ, "Hervás, tierra del agua, ciudad moderna y pueblo medieval: un ingerto poético en tierras extremeñas", Semanario El Español (16 de junio de 1956); reproduccido en $F F H$ (1956), pp. 15-33; A. ENRIQUe SánCHEZ, "Hervás, villa hechicera", $F F H$ (1958), pp. 19-21, p. 21; (artículo sin firmar) "Nuestros municipios. La villa de Hervás (Cáceres)", Municipalia, VII (julio 1959), pp. 18-19; G., "A ti que no conoces Hervás", $F F H$ (1961), pp. 95-99, p. 95; D. SALAS, "Hervás, diversidad y síntesis, $F F H$ (1962), pp. 27-39, p. 39; N. CARRASO ARAUZ, "Esmeralda del agua", $F F H$ (1962), pp. 51-59, p. 53; M. RODRíguez BRUÑo, "Trasuntos de Hervás", FFH (1962), pp. 61-71, pp. 63-65; F. Llopis Planell, "Esa noble Villa de Hervás...”, FFH (1962), pp. 73-89, p. 79; V. MONTES, "Poblamiento", FFH (1965), pp. 29-33; E. SERRANO DíaZ, "Sorpresas de España. Hervás", FFH (1967), pp. 5-9, p. 9; R. CARNICER, Las Américas peninsulares. Viaje por Extremadura (Barcelona, 1983), p. 58.

12 Arriba (Madrid, 10 de mayo de 1972), p. 21; reproduccido en $F F H$ (1972), p. 9. 
cían la industria y auxiliaban a los señores y aun a los suyos en sus apuros para las levas y compromisos de guerra.

El Ayuntamiento envió el expediente en el que se insertó esta "información" a la Real Academia de Bellas Artes de San Fernando, que, el 21 de noviembre de 1966, nombró al escultor hervasense E. Pérez Comendador ponente de la Comisión Central de Monumentos. Bellas Artes remitió un informe favorable al Ministerio de Educación y Ciencia (17 de junio de 1968), reduciendo la judería a la "calle de la Cuesta, puente romano y calles del Vado, Rabilero y Sinagogan. No obstante, el Ministerio de Educación y Ciencia declaró conjunto histórico-artístico la "judería" de las $12 \mathrm{ca}-$ lles (24 de enero de 1969), ratificado por el Consejo de Ministros en el Real Decreto 308/13 de febrero de 1969, suscrito en el BOE de 3 de marzo de 1969 y en el Boletín Oficial de la provincia de 7 de marzo de $1969^{13}$. De esta manera, el Estado consagró oficialmente la "judería" hervasense. Ante la importancia "histórica" que el barrio "hebreo" fue adquiriendo en la región, la Junta de Extremadura, basándose en la Ley del Patrimonio, aprobada por el Gobierno en 1985, la declaró Bien de Interés Cultural. Aunque algunos cronistas regionales no se adaptaron al nuevo diseño judaico que situaba la judería en el barrio del Rabilero ${ }^{14}$, la mayoría de los escritores sí se ajustaron al patrón oficial ${ }^{15}$. En 1987-88, la Dirección General

13 Archivo Municipal de Hervás, leg. 183, expte. 7: “Expediente sobre solicitud a la Real Academia de la Historia o a la de Bellas Artes de que se declare monumento histórico-artístico el barrio judío de esta villan; y Ministerio de Cultura, Archivo Central, caja 87659, núm. de registro 2055: "Hervás (Cáceres). Barrio judío de Hervás CHA». Véase mi artículo "Barrio judío de Hervás: Conjunto Histórico Artístico", El Compadre Noticiero, II, núm. 12 (marzo de 1993), p. 5.

14 A MUÑOZ DE LA PEÑa, "El barrio judío de Hervás", Hoy (Badajoz, 1969), en fecha que desconozco; reproducido en $F F H$ (1969), p. 25; y en $F F H$ (1995) [pp. 62-63]; P. NERIA, "Hervás al día", $F F H$ (1982) [pp. 7-21, p. 11].

15 N. SÁNCHEZ MORAlES, “Hervás: temas y variaciones", FFH (1970), pp. 7-11, pp. 9-11; V. SERrano, "Amistad Judeo-Cristiana en Hervás. 9 de mayo de 1971", FFH (1971), pp. 23-25, p. 23; J. L. ÁlvareZ MARTíneZ, "La judería hervasense", FFH (1975), pp. 9-13, p. 11; J. C. RODRíGUEZ IBARRA, "El presidente de la Junta de Extremadura", FFH (1988), pp. 7-9, p. 7; M. CARDAlliagueT, Historia de Extremadura (Badajoz, 1988), pp. 102 y 114; S. ORDAX y OTROS, Monumentos artísticos de Extremadura (Mérida, 1988), pp. 320-325, p. 324. El callejero judío de J. SÁNCHEZ RODRíGuEZ abarcó 12 calles. Ver FFH (1990) [pp. 33-35]; V. GINARTE, Hervás: su bistoria, su tierra, su gente (Madrid, 1991), p. 139; C. MASSA, «Un pueblo errante», La Prensa (Buenos Aires, 16 de noviembre de 1991); A. SÁNCHEZ MANZANO, "Hervás, un privilegio", Hoy (Badajoz, 5 de enero de 1992), p. 27; F. FIDAlgo, "Hervás", El País Semanal, XVII (Madrid, 9 de febrero de 1992), pp. 90-91; A. VÁZQuEZ, "Saludo del presidente de la Asamblea de Extremadura", $F F H$ (1993) [pp. 7-8]; P. CALVo, "Barrio judío, año cero", Foro de la vida 
de Ordenamiento del Territorio y Urbanismo de la Junta de Extremadura acordó preservar la «juderían, elaborando el Proyecto Especial de Protección y Rehabilitación del Casco Antiguo y Barrio Sefardita de Hervás (PEPYRCABS), que ejecutó parcialmente el Ayuntamiento a través de varias escuelas taller (1989-1997). De esta manera, con el aval de las instituciones, Hervás convirtió su "barrio judío" en el símbolo identificador de la comunidad. Ante la falta de una documentada historia hebrea, y de interés y provisión de medios para realizarla de modo riguroso y científico, desarrolló una colección de fábulas pseudohistóricas que justificaran un pasado judío ${ }^{16}$, que la documentación histórica que hasta el momento se ha podido reunir presenta de manera muy distinta a la que hoy es "oficial.

\section{TRADICIONES INVENTADAS SOBRE LOS ORÍGENES DEL TOPÓNIMO HERVÁS}

Las primeras interpretaciones sobre el topónimo "Hervás" son del siglo Xvil y se las debemos al fraile A. Fernández: aes tradicion que Ervas tierra de Bejar, y Segura, aldea desta ciudad [de Plasencia] fueron de la religion de los Templarios" ${ }^{17}$. Muy distinta es la reflexión del bachiller P. de Aguilar, convencido en 1776 de que uel nombre antiguo y moderno de este pueblo [...] es Hervas [...] unos dicen es acaso [por] la mucha abundancia de hierbas que en [el] territorio se crian, otros por una hermita que habia y estaba dedicada a san Herbasion ${ }^{18}$. No fue hasta mediados

judía en el mundo, 68 (México, noviembre de 1994), p. 523; El Ausente. Boletín informativo, núm. 11 (enero de 1995), pp. 5-10; S. SÁNCHEZ GonZÁlEZ, "Hervás integrada en los Caminos de Sefarad", Hoy (Badajoz, 18 de febrero de 1995), p. 27; (artículo sin firmar), "Viajes", El País de las Tentaciones, núm. 83 (Madrid, 26 de mayo de 1995), p. 31; E. Bastida Vicario, "Hervás", Guía del Ocio (Madrid, 11 de julio de 1995), p. 38; E. NERIa Castellano, Hervás, tentación natural Guia turístico-comercial (Plasencia, verano de 1995), p. 7; J. C Rodríguez IBarRA, "Saludo del Presidente de la Junta", FFH (1995) [p. 6]; A. Ventura DíAZ, "Extremadura lugar de encuentro", Raíces. Revista Judía de Cultura, núm. 21 (invierno 1994), p. 66; G. KoHAN, "Reconstrucción del barrio judío de Hervás", Raíces. Revista Judía de Cultura, núm. 28 (otoño 1996), pp. 64-66.

16 Véase J. M. PEDROSA, "Visión de lo judío en la cultura popular extremeña", Actas de las Jornadas Extremeñas de Estudios Judaicos (Badajoz, 1996), pp. 249-283.

17 A FERNÁNDEZ, Historia y anales de la ciudad y obispado de Plasencia (Madrid, 1627), f. 58. Esta tesis fue compartida por F. MARTínez SERRANO: "Santi-Hervás, un convento de templarios con la advocación de los santos Gervasio y Protasio; y refiere la tradición que á este santuario se debe la fundación del pueblo, de su firme puente, y el nombre del río y del lugar»; cfr. Memorias (Cáceres, 1843), 2. ${ }^{2}$ ed., p. 39, citado por V. PAREDES, "Hervás” p. 101.

18 La provincia de Extremadura al final del s. XVIII, pp. 238-240, p. 239. 
del siglo XX cuando se introdujeron los primeros referentes judaicos. Para E. González «según la leyenda y debido a un nefasto crimen [...] se produjo el milagro de una conversión total de aquellos [judíos] al cristianismo, cambiando el antiguo nombre de Ambroz por el de Gervasio o Hervás, tomado del mártir patrón San Gervasio ${ }^{19}$. En 1962, M. Rodríguez Bruno rizó el rizo apuntando que Hervás fue aromana en su nombre, árabe en su barrio judío, y cristiana en su patrona Nuestra Señora de las Aguas Vivas $^{20}$. Yo mismo debo admitir que cuando aún no había iniciado mi trayectoria investigadora aventuré sin ninguna base científica que "río Ambroz, [es] palabra de origen sefardita" ${ }^{21}$, imprudencia en la que también incurrió M. Sayáns Castaños, quien, al comentar la especial orografía del monte de Hervás, afirmó que era un monte «hundido", lo que transformado en "huío" llevaba al "juío" extremeño ${ }^{22}$. Aún más peregrino es el anacronismo difundido en un folleto de propaganda turística en forma de estrella de David que circula actualmente por Hervás con la información de que aaunque por su situación [Hervás] debió acoger a judíos con anterioridad, es en 1133 cuando debieron establecerse coincidiendo con la conquista de las ciudades de la zona por parte de Alfonso VIII. Asombrosa concreción de detalles, cuando la historia dice que el monarca reinó en Castilla de 1158 a $1214^{23}$. Y disparate sólo equiparable al de los divulgadores que sostienen que "los judíos debieron llegar aquí en el siglo $\mathrm{XI}^{2{ }^{4}}$, en cuya fecha aún no se había fundado el lugar de Hervás, o que desplazan su llegada a finales del siglo XII ${ }^{25}$, datos todos ellos errados por cuanto las primeras referencias sobre la presencia de los judíos

19 E. GoNZÁlEZ, "Amor sin venda", $F F H$ (1959), pp. 7-11, p. 9.

20 M Rodríguez Bruno, "Trasuntos de Hervás”, FFH (1962), pp. 61-71, p. 71. E. BASTIDA Vicario, en "Hervás", Guía del Ocio, p. 38, apunta orígenes árabes y repoblaciones templarias y hebreas.

21 M. Martín, "Barrio judío", FFH (1983), pp. 69-72, p. 70.

22 M. SAYÁNS CASTAÑOS, "La revolución Laramida y nuestras montañas", conferencia impartida en Hervás el 11 de agosto de 1991. Véase la crónica periodística firmada por J. L.: "Sayáns habló a los hervasenses de la existencia del desaparecido "monte juío, Hoy (Badajoz, 16 de agosto de 1991), p. 13, recogido en El Ausente. Boletín informativo, núm. 7 (1991), p. 7.

23 La publicidad es un folio en forma de estrella de David denominada Caminos de Sefarad con un subtítulo en hebreo. No consta ni fecha ni lugar de edición.

24 P. Alonso y A. GIL, La memoria de las aljamas. Paseo por las juderias españolas (Madrid, 1994), p. 90.

25 Caminos de Sefarad, coordinado por el Patronato para la Promoción del Turismo y la Artesanía de la Provincia de Cáceres (Salamanca, 1995), p. 5. El capítulo alusivo a Hervás está sin firmar. 
en Hervás las encontramos en el reparto del "servicio y medio servicio" de las rentas de Castilla, en $1464{ }^{26}$.

TRADICIONES INVENTADAS SOBRE LA SINAGOGA QUE TENÍA UNA PILA BAUTISMAL Y UN ALTAR

Los autores que han opinado sobre el pasado judío de Hervás emplearon criterios dispares. En ocasiones, creyeron a pies juntillas en la realidad de lo que aseguraban, y otras veces eran conscientes de que hacían simples ejercicios de ficción literaria. En la mayoría de los casos confundieron la materia histórica con la fábula y no supieron deslindar muy bien si escribían historia, leyenda o incluso poesía ${ }^{27}$. De cualquier modo, todavía existen lectores que creen en la infalibilidad de la letra impresa, y a ello se debe que en el pueblo hayan prendido las opiniones vertidas por personalidades consideradas prestigiosas desde el punto de vista político o intelectual, cuando en realidad han estado transmitiendo una visión deformada del pasado judaico hervasense; una visión que ha interferido tardíamente en la tradición oral y desorientado completamente al lugareño. A. Manzano defendió que la existencia de una tradicional acalle de la Sinoga [...] prueba que en ella había un templo judaicon. En cambio, los hervasenses le comunicaron a V. Paredes en 1897 que la sinagoga se encontraba en el número 19 de la calle Rabilero. Pero como al arquitecto Paredes no le gustó la faz del templo judío del Rabilero, lo emplazó en la calle Sinagoga: "en estas casas no estuvo la sinagoga sino en la calle de la Sinogan, rectificando la tradición oral ${ }^{28}$. F. Cantera Burgos fue informado en junio de 1954 de que en ala calle Rabilero estaba el templo judaico" ${ }^{29}$, desmintiendo a Mélida años después:

26 L SUÁREZ FERNÁNDEZ, Documentos acerca de la expulsión de los judíos (Valladolid, 1964), p. 66; M. A LADERO QueSADA, "Las juderías de Castilla según algunos "servicios" fiscales del siglo XV", Sefarad, XXXI (1971), pp. 249-264, p. 262; y F. CANTERA BuRgos (en colaboración con C. CARRETE), «Los repartimientos de Rabí Jaco Aben Nuñes", Sefarad, XXXI (1971), pp. 213-250, p. 242.

27 M. Álvarez EnCINAS, "La leyenda de la Fuente Chiquita", $F F H$ (1951), pp. 40-43; A. MuÑoz DE la PeÑa, "El barrio judío de Hervás”, FFH (1969), pp. 25-29; E. GonZÁlez, "Hervás. Canto al amor verdadero", FFH (1953), pp. 7-11; F. MARCOS CaliEjA, "Dalila, leyenda romántica de Hervás", FFH (1969), pp. 77-91; V. SERRANO, “Amistad JudeoCristiana en Hervás", FFH (1971), pp. 23-25; V. MUÑOz MUÑoz, "Romance del cristiano y la judían, FFH (1994) [p. 110]; J. SENDín BLÁZqueZ, Calzada y camino de Santiago. Via de la Plata. Historia-Mito-Leyenda (Zamora, 1992), pp. 181-186.

28 V. PAREDES, “Hervás", pp. 168-174, p. 174.

29 F. CANTERA, Sinagogas españolas (Madrid, 1978), p. 228. 
lo cierto es que la calle de la Sinagoga es otra más corta y modesta [...] No se descubren vestigios arquitectónicos de especial interés [...] En cuanto al nombre del Rabilero, no puede juzgarse que ese nombre envuelva el de rabino y sea corrupción de Rabilero, según afirmaba el inolvidable maestro don José Ramón Mélida ${ }^{30}$.

El divulgador J. García Atienza tampoco se enteró muy bien de dónde estaba la sinagoga:

al final de la calle Rabilero, a la derecha, se abre la calle de la Sinagoga. El número 1 de esta calle [se refiere al 48 de la calle del Moral] es la casa que tradicionalmente se señala como sinagoga de la antigua comunidad [...] El tejado tiene una parte central más levantada, como si en tiempos pasados hubiese estado dividida en tres naves, la central más alta que las laterales.

Atienza insertó una fotografía de la citada casa con un burro paseando por la calle ${ }^{31}$, fotografía con la que los redactores de Historia 16 ilustraron un artículo de J. Valdeón ${ }^{32}$, y que de nuevo reproduciría Atienza en 1994, con la novedad de que ahora insertaba la fotografía del pollino al revés ${ }^{33}$. En una nueva escalada de despropósitos, el autor anónimo del epígrafe "Hervás", incluido en una guía de la España judía, llegó a fantasear que la sinagoga debió ser un "centro educativo y difusor de cultura a través, sobre todo de la Escuela Talmúdica, [y] se citaba entre las más importantes de la provincia, junto a la de Cáceres o Plasencia" ${ }^{34}$. Las teorías de estos intelectuales y pseudointelectuales se han superpuesto y desorientado a la tradición oral en las dos últimas décadas, y si hasta fecha muy reciente los hervasenses pensaban que la sinagoga debió estar en la casa número 13 de la calle Sinagoga, ahora ha cobrado nuevos vuelos la tradición primitiva que la sitúa en la del Rabilero, 19. La investigación de archivo permite averiguar que la sinagoga era propiedad de rabí Simuel, pero no alcanza a despejar la incógnita de su emplazamiento urbano. Lo que únicamente se puede añadir es que la

30 F. CANTERA, "Informe sobre solicitud del Ilustre Ayuntamiento de Hervás (Cáceres) pidiendo que el Barrio Judío de la villa sea declarado conjunto histórico-artístico, Boletín de la Real Academia de la Historia, CLXVIII (1971), pp. 388-391, p. 390.

31 J. G. Atienza, Guia judia de España (Madrid, 1978), p. 174. E. Neria CastellaNO sitúa el templo hebraico en la calle Sinagoga; cfr. Hervás, Tentación Natural, p. 8.

32 J. VALDEÓN, «De la convivencia a la expulsión”, Historia 16, VI, núm. 58 (Madrid, febrero de 1981), pp. 62-67, p. 64.

33 J. G. ATIEnZA, Caminos de Sefarad: Guía judia de España (Barcelona, 1994), p. 217.

34 Caminos de Sefarad (Salamanca, 1995), pp. 48-57, p. 51. 
calle Sinagoga aparece citada por primera vez en el padrón municipal de $1872^{35}$

La idea de que en la sinagoga de Rabilero "se conservó hasta hace poco la pila de abluciones reglamentaria" pudo partir de J. Rodríguez Trinidad, que así se lo comunicó al profesor F. Cantera en $1954^{36}$ y al periodista J. Jiménez en 1956; a quien, además, le informó de que por 200 pesetas «un anticuario barcelonés se llevó hace poco [de la sinagoga] una hermosa tabla con un sol tallado" ${ }^{37}$. También A. Muñoz de la Peña evocó la pila judaica en $1969^{38}$; y en la década de los ochenta - y en la actual- escuché en las calles del barrio hebreo que era la pila bautismal de los judíos. En realidad, la pila de abluciones - una pila de agua bendita- y la tabla tallada - procedente de un altar cristiano dedicado a san Francisco- pertenecían a la capilla que había en el interior de la enfermería de los padres franciscanos y fueron trasladadas a la casa de la "sinagoga" de la calle Rabilero en 1873, como consecuencia de la desamortización de Mendizábal, para acomodar en su interior el Ayuntamiento ${ }^{39}$.

\section{LA INVENCIÓN DE UN «MURO DE LAS LAMENTACIONES"}

No todas las fábulas sobre el pasado judío de Hervás inventadas en los dos últimos decenios han sido aceptadas y asumidas por la tradición local e institucional. En la década de los ochenta de la presente centuria oí hablar a los diversos guías eventuales de un "muro de las lamentaciones" ubicado en una plazoleta del barrio judío, cuya imaginaria existencia ingenuamente contribuí a propagar:

la calle de la Cuestecilla es una de las dos entradas oficiales a nuestra aljama, que desemboca en la única plaza existente en el barrio. Por su forma, y la existencia de una pared redondeada, puede pensarse que adquiere la forma de un

35 Archivo Municipal de Hervás, legajo 103, carpeta 5: «Padrón de habitantes de 1872 , sin foliar.

36 F. CANTERA, Sinagogas españolas, p. 228.

37 J. JimÉNEZ, «Hervás, tierra del agua...n, El Español (16 de junio de 1956); reproducido en $F F H$ (1956), pp. 15-33, p. 29.

38 A. MuÑoz, "El barrio judío de Hervás", $F F H$ (1970), pp. 25-29, p. 27.

39 Archivo Municipal de Hervás. Actas de 1873. Caja libro 27, libro 187; J. CHAMORRO, "Del ayer centenario. Año MDCCCLXXIII", $F H H$ (1973), pp. 13-33, p. 15; y V. PAREDes, «Hervás”, p. 174. 
muro de las lamentaciones, donde los hebreos suelen reconocer sus errores y hacen promesas y peticiones ${ }^{40}$.

Lo curioso del tema es que a V. Ginarte le sedujo el invento y lo trasladó a su libro ${ }^{41}$. Afortunadamente, P. Alonso y A. Gil descalificaron tal tesis: "la existencia de una pared redonda ha sido interpretada por un cronista local, no sin cierta fantasía, como el lugar del muro de las lamentaciones $^{42}$. La fabulosa invención no ha vuelto a ser tenida en cuenta por ninguna fuente - al menos escrita- posterior. La credulidad del pueblo y la manga ancha de la letra impresa tienen, por fortuna, sus límites.

\section{FÁBULA DE LOS JUDÍOS PRESTAMISTAS}

En el Archivo Histórico Nacional se conserva el padrón hebraico con los nombres y apellidos de los 45 judíos que vivían en Hervás en 1492 y con el dato de que 12 de ellos carecían de bienes inmuebles. Entre los menesterosos judíos estaban Jaco Cohen, Lunbroso y Ximo Calderón, y entre los propietarios figuraban Mose Salvadiel, Don Sento - de oficio texedor-, Jaco Salvadiel, Mose Zarco, Yuçe Zarco, Çalama el Luengo, Yuçe Abenfariz, Bellida la Rica, rabí Simuel, etc ${ }^{43}$. A raíz de la publicación por el bejarano J. Muñoz García, en 1936, del padrón hebraico ${ }^{44}$, las fábulas preexistentes - desde no hacía mucho tiempo- sobre riquísimos prestamistas judeohervasenses se revistieron con los antropónimos de diversos judíos que habían vivido en Hervás en el siglo xv. Lo curioso es que dos de aquellos supuestos "banqueros" - Jaco Cohen y Ximo Calderón-, a quienes las nuevas leyendas atribuyeron tratos y préstamos a los reyes de Castilla, figuraban como indigentes en el padrón hebraico. El nuevo desatino pseudohistórico cobró alas con la intervención de J. Rodríguez Trinidad, que publicó el censo hebreo con errores de transcripción paleográfica en 1956:

los hermanos Cohen Salvadiel, Moze Zarco, Jacob Cohen, Camala del Luengo, Haben Haxiz, Rabi Samuel, Lombroso, Bellida la Rica, Don Sento Texedor, Simón

40 M. Martín, "El barrio judío", FFH (1983), pp. 69-72, p. 70.

41 V. GinaRTE, Hervás: su bistoria, su tierra, su gente, p. 131.

42 P. Alonso y A. GIL, La memoria de las aljamas. Paseo por las juderias españolas, p. 93 .

43 M. DE Hervás, “Los judíos de Hervás”, pp. 58-70, p. 63.

44 J. MuÑoz, «Hebreos que vivían en Hervás”, Béjar en Madrid, XX, núm. 788 (Madrid, 1936), p. 5. No cita sus fuentes de información. 
Calderón, Orabuena... Gente que ejercía la industria y auxiliaba a los señores, y aún a los reyes en sus apuros para las levas y compromisos de guerra ${ }^{45}$.

$\mathrm{Ni}$ qué decir tiene que la sugestiva propuesta de los judíos usureros codeándose con la realeza castellana fue acogida con notable entusiasmo e incorporada sin paliativos al acervo credencial del pueblo ${ }^{46}$. A pesar de que el escritor V. Chamorro ironizó sobre tal fábula, escribiendo: "dicen que en Hervás vivió una colonia con nombres tan famosos como los Cohen, los Aben Haxiz, los Bellida la Rica, acostumbrados a cobrar, de interés, una meaja por maravedís a los que los propios reyes acudían", y señalando que "algunos turistas tienen dificultad en comprender cómo semejantes adinerados pudieron habitar en estrechas viviendas que parecen cábalas, con la planta baja dedicada al asno" ${ }^{47}$, la tradición del pueblo y de la letra impresa persiste en el sugerente cliché de los judíos prestamistas y amigos de los reyes de Castilla ${ }^{48}$.

\section{FÁBULA DEL CENTINELA Y DEL GUETO JUDío}

En 1355 existía en Hervás el "monte castañar" y el "puente de la Centenera", como demuestra un pasaje del Libro de la Montería de Alfonso IX: «desde la peña de Pie Naharron por collado Sequiello fasta el collado de la Centenera e la otra desde las viñas de la puente Centenera" ${ }^{49}$.

45 Cfr. J. JimÉNEZ, «Hervás. Tierra del agua...”, FFH (1956), pp. 15-33, p. 29.

46 A Maíllo García, "Hervás o la Evocación”, FFH (1970), pp. 31-35, p. 35; L. CORTÉS VÁZQUEZ, conferencia pronunciada en el Colegio Universitario de Cáceres el 14 de mayo de 1973, recogida en Viaje literario al norte cacereño (Salamanca, 1973), he consultado la 3..$^{\text {e }}$ edición (Salamanca, 1984), p. 13; recogido en $F F H$ (1973), pp. 99-103, p. 99; y FFH (1995) [p. 64-65]; J. GARCíA ATIENZA, Guía judía de España, p. 174; y Caminos de Sefarad, p. 217; L. BORRÁs y E. BARBÉ, Extremadura. Guía del viajero (Madrid, 1991), p. 35.

i7 V. CHAMORRO, Guía secreta de Extremadura (Madrid, 1976), pp. 24-25; y Por Cáceres de trecho en trecho (Madrid, 1981), pp. 13-14.

48 M. a Teresa RODRígueZ, "Reseña histórica de la Villa de Hervás", FFH (1974), pp. $27-$ 33, p. 29; reproducido en FFH (1995) [pp. 66-68]; E. SÁNCHEZ ALEGRía, „Hervás, antiguo feudo de judíos ricos", Extremadura (Cáceres, 13 de noviembre de 1982), p. 12; F. BuLLÓN INFANTE, «Hervás y su agricultura de montaña», $F F H$ (1986) [pp. 85-87, p. 85]; A. VÁZQUEZ, "Saludo del Presidente de la Asamblea de Extremadura", FFH (1993) [pp. 7-8, p. 8]; P. Alonso y A. GIL, La memoria de las aljamas. Paseos por las juderías españolas, p. 92.

49 ALFONSO IX, Libro de la Montería (1582), volumen II, libro tercero, p. 42; V. PAREDEs, en "Hervás», p. 99, recoge un documento de principios del siglo XV que cita el "monte de la centenera". 
El monte de la centenera dio su nombre a la calle Centenera -que luego derivó en Centiñera-, a la Cuestecilla de Centiñera y al puente de Centiñera - hoy, de los Molinos-, cuyo emplazamiento fue urbanizado en el decurso de los siglos XVI y XVII. Sin embargo, en el último tercio del siglo XIX, la tradición popular, alentada por alguno de sus ingeniosos moldeadores, dio alas al arquetipo de los judíos y cristianos medievales enfrentados por enemistades, odios y venganzas que obligaron a los reyes de Castilla y a los señores feudales a recluir a los judíos en guetos separados de los barrios cristianos. De este combinado artificioso bebió A. Manzano cuando difundió en 1886 que

desde el castillo parte otra calle que separa el pueblo en dos mitades, nueva y vieja, y á la parte opuesta una plazoleta llamada Cantón de Centiñera, donde es creỉble hubiese un centinela, que en unión del que habría en el castillo, estuviesen destinados á impedir el trato de los judíos con los cristianos ${ }^{50}$.

V. Paredes rechazó la existencia del gueto judío imaginado por Manzano en $1907^{51}$, con resultado tan notable que nadie en la localidad se ocupó de ello hasta que casi setenta años después un hervasense cuya identidad desconocemos repescó un elemento casi olvidado de la historia para comunicárselo a un periodista. El informante anónimo fabricó su propia fábula, relacionando el origen del nombre de la calle "Vedelejos" con un supuesto centinela cristiano apostado en la calle Centiñera que desde su atalaya "ve de lejos" y vigila el gueto judío ${ }^{52}$. La bola de nieve fue ampliándose en los años siguientes ${ }^{53}$ hasta llegar a la abultadísima versión actual, que presenta a un centinela apostado en la casa número 1 de la calle Centiñera tocando una campanilla cada vez que "ve de lejos" a un judío subiendo por la calle de la Cuestecilla para que los cristianos se escondan en las casas.

50 V. PAREDES, "Hervás", p. 99.

51 Ibidem, p. 105.

52 (Artículo no firmado), "El barrio judío de Hervás", El Alcázar (Madrid, 2 de marzo de 1972), cuya página desconozco; reproducido en $F F H$ (1972), p. 9.

53 M. MARTín, «Hervás. Barrio judío", FFH (1983), pp. 69-72, p. 70; E. C. DE SANTOS, La Historia medieval de Plasencia y su entorno geo-bistórico: la sierra de Béjar y la sierra de Gredos (Cáceres, 1986), p. 532; J. FERRERO, "Los pasos perdidos de Rabí Samuel", El País (Madrid, 5 de agosto de 1991), p. 9; P. SÁnCHEZ, "Esos pueblos tan lindos", Hoy (Badajoz, 1 de marzo de 1992), p. 36; P. Alonso y A. GIL, La memoria de las aljamas. Paseos por las juderias españolas, p. 95; E. NeRIA CASTELlano, op. cit., p. 8. 
LAS Falsas leyendas Del CRImen DE LA Fuente Chiquita y DE LA MaRuja, LA JUDÍA ERRANTE

En la segunda mitad del siglo $\mathrm{xx}$, el folclor hervasense fue ampliando su repertorio con nuevas invenciones pseudohistóricas, muchas de ellas de inspiración individual y carentes de cualquier base folclórica previa. Algunos espíritus más o menos ilustrados gestaron fábulas que no cuajaron ni en los lectores de la época ni en la tradición popular, porque a sus invenciones les faltaron o no desarrollaron bien los aderezos propios del folletín: judíos malévolos, amores contrariados entre miembros de distintas confesionalidades, traiciones religiosas y crímenes ${ }^{54}$. Tales elementos sí fueron combinados, y con inusitada fantasía, por el rapsoda E. González en su poema "Hervás. Canto al amor verdadero" "55, que evoca una Hervás originariamente habitada por una comunidad judía que vivía apaciblemente hasta que un buen día se establecieron allí los cristianos. El baldón del deicidio de Cristo achacado a los judíos por los cristianos motivó la marginación de los primeros, lo que no pudo evitar que la hija del rabí se enamorase de un cristiano que le adoctrinó en su religión. Un judío celoso enamorado de la muchacha mintió al rabí diciéndole que su hija contaba a los cristianos secretos de raza. Al mismo tiempo que la hebrea se convertía al cristianismo, siete puñaladas judías tronchaban de raíz el amor y la vida de los dos amantes. El cura de Hervás, cual justiciero Vicente Ferrer, se personó en el lugar del crimen, la Fuente Chiquita, y arengó a los judíos deicidas de tal forma que pidieron a gritos el bautismo. Como si esta fábula fuese real, J. Rodríguez Trinidad la relató al periodista J. Jiménez, que no tardó en publicarla ${ }^{56}$, mientras que el autor de la composición es probable que se lo contase a su amigo el conde de Canilleros ${ }^{57}$, cuyo relato, novelado, acabó convirtiéndose al cabo del tiempo en un best seller nacional ${ }^{58}$.

54 Tal sucedió con las fábulas imaginadas en M. ÁLVAREZ ENCINAS, «La leyenda de la Fuente Chiquita", $F F H$ (1951), pp. 40-43; recogido en $F F H$ (1994) [pp. 34-36]; A. MuÑoz DE LA PEÑa, "El Machón de Hervás", FFH (1962), pp. 41-49; F. Marcos CallejA, "Dalila. Leyenda romántica de Hervás", FFH (1969), pp. 77-91.

55 E. GoNZÁLEZ, FFH (1953) pp. 7-10. Publicó otra versión con ligeras modificaciones en "La hija del rabín, Mis versos de ayer y boy (Madrid, 1971), pp. 161-167.

56 J. JiMÉnEZ, "Hervás. Tierra del agua...», FFH (1956), pp. 15-33, p. 27.

57 M. MUÑOZ DE SAN PEDRO, Extremadura (la tierra en la que nacian los dioses) (Madrid, 1961), p. 124.

58 Efectivamente, fue recordado por F. TORROBA, Los judios españoles (Madrid, 1967), p. 139; C. MUÑOZ COMENDADOR, "La tierra madre, $F F H$ (1975), pp. 23-25, p. 23; 
Para enredar aún más el ya intrincado ovillo, a esta leyenda se le han incorporado ocasionalmente otros elementos que le han dotado de renovadas y complejas apariencias. Tal es el caso de la fábula de la Maruja que, según M. Álvarez Encinas, es el viento nocturno invernal que suena cuando desciende la princesa romana Clodia envuelta entre las aguas del río Ambroz ${ }^{59}$, mientras que para J. Sánchez Matas es el silbido del vendaval producido a través de la campana de la chimenea ${ }^{60}$, y para J. Chamorro Martín es ael solano - llamado maruja (onomatopeya del ruido que hace un soplido al cruzar el monte) - [o] viento del SO, favorable a las lluvias" ${ }^{61}$. La poderosa imaginación de J. Sendín sobreimpresionó la ventolera de la Maruja sobre el crimen de la Fuente Chiquita de esta guisa:

en Hervás, en determinados días, sobre todo de invierno, baja desde Pinajarro un vientecillo salpicado de lágrimas, que produce un extraño rumor como de alguien que llora. Los lugareños lo llaman "el quejíon, equivalente a grito o suspiro, y dicen que son los suspiros de Julián y de Maruja que recuerdan a toda la villa el incomprensible martirio de la pareja de enamorados ${ }^{62}$.

El mismo J. Sendín, en otro libro, agregó al cuento de E. González la leyenda del centinela, el gueto judío y la Maruja, pergeñando una inaudita mezcolanza antisemita titulada "Amor y sangre en la judería" ${ }^{63}$, en la cual bautizó a todo el innominado elenco de E. González, y llamó Ismael al rabino, Maruxa o Maruja a su hija la judía enamorada, Julián al novio cristiano y Dimas al judío traidor. Añadiendo además la figura de Zoilo, el confidente hebreo que incendió de celos a Dimas contándole las aventuras amorosas de la pareja. Algunos episodios de la leyenda reinventada por J. Sendín no tienen desperdicio, como el que narra la venganza del malvado Dimas, que "consiguió reunir una pandilla de amigos, Zoilo, Benito (Baraj), Fructuoso (Efraín) e Ismael (Jacobo), muchachos de catadura muy similar a la suya que juramentaron para acabar con los amores del cristia-

V. CHAMORRo, Guía secreta de Extremadura, pp. 25-26; y Por Cáceres de trecho en trecho, p. 14; J. GarCía ATIEnZA, Guia judía de España, p. 174; y Caminos de Sefarad, p. 217; P. AlONSO y A. GIL, La memoria de las aljamas. Paseos por las juderias españolas, pp. 93-95; y El Compadre Noticiero, II, «La hija del rabín, núm. 13 (abril de 1993), p. 3 .

59 M. Álvarez, "La leyenda de la "Fuente Chiquita", FFH (1951), pp. 40-43, p. 43.

60 J. SÁNCHeZ MATAS, "Monte castañar gallego", $F F H$ (1951), pp. 47-49, p. 47.

61 Recogido por FRESNO DE RIBERA-HOZ SECA, Diccionario geográfico de España (Madrid, 1959), X, p. 582.

62 J. SENDín, Calzada y camino de Santiago. Vía de la Plata. Historia-mito-leyenda, pp. 184-186.

63 J. SENDín, ibidem, pp. 184-186; y Leyendas Extremeñas (León, 1987), pp. 113-119. 
no y la judíam. Tras añadidos tan desafortunados como éste, J. Sendín reconcilió a judíos y cristianos en un lazo perdurable: «en Julián y Maruja se abrazaron por primera vez las dos razas que luego sin odios ni sangre terminarían por ofrecernos el espectáculo de la Hervás actual.. La fábula de J. Sendín ha echado fuertes raíces en la tradición pseudolegendaria hervasense, como demuestran las reelaboraciones y menciones que aún hoy siguen apareciendo a buen ritmo ${ }^{64}$. En su nueva versión, la Maruja se ha convertido en la judía errante, alma en pena agorera, anunciadora de malos presagios ${ }^{65}$.

\section{LA INVENCIÓN DEL "MACHÓN" DEL PUENTE}

En el puente de la Fuente Chiquita está adosada —desde época que no ha podido ser determinada - una lápida sepulcral de granito llamada popularmente el "Machón". De ella se ha dicho que era la efigie de un Carvajal, de un guerrero y de un pastor lusitano ${ }^{66}$, hasta que - ¿cómo no?- los imaginativos recreadores de la cultura local la han relacionado con el judaísmo. En 1953, E. González la definió como testimonio de la confraternización judeocristiana ${ }^{67}$, opinión que encontró eco en M. Muñoz de San Pedro en $1961{ }^{68}$. En 1962, M. Sánchez-Mora descu-

64 (Artículo sin firmar), Catálogo Escultura con futuro, "Maruxa" (Ayuntamiento de Cáceres, 1989) [p. 19]; (artículo sin firmar), "Maruxa”, El Compadre Noticiero, II, núm. 21 (diciembre de 1993), p. 1; A. T. B., "Historia", El Compadre Noticiero, III, núm. 30 (septiembre de 1994), p. 4; P. Alonso y A. GIL, La memoria de las aljamas. Paseos por las juderias españolas, pp. 93-95; V. MUÑOZ MUÑOZ, "Romance del cristiano y la judía", FFH (1994) [p. 110]; A. ROA Cilla y M. GÓmEZ ANDREA, Hervás, imágenes de su bistoria (Madrid, 1996), pp. 2 y 9; L. ReNSOLI, "Ana, Maruxa y el Rabino", Raíces. Revista Judia de Cultura, núm. 28 (otoño, 1996), pp. 34-39.

65 (Artículo sin firmar), Caminos de Sefarad (Salamanca, 1995), pp. 57-63, p. 60; L MEdiNa García, "Hervás, monumento a la tradicionalidad judía", pp. 37 y 39; (sin firmar), "Por los kaminos de Sefarad. Hervás", Akí Yerushalayim, 17, núm. 53 (1996), pp. 5-7, p. 6; L. ReNSOLI, "Ana, Maruxa y el Rabino", pp. 34-39.

66 J. R. MÉLIDA, Catálogo monumental de España. Provincia de Cáceres, pp. 235236; J. SÁNCHEZ MATAS, "Antiguas construcciones de Hervás", FFH (1948) [p. 7-9]; M. Álvarez EnCinAS, "La leyenda de la "Fuente Chiquita", FFH (1951), pp. 40-43; L. BORRÁs y E. BARBÉ, Extremadura. Guía del viajero, pp. 35-36.

67 E. GonZÁlez, "Hervás. Canto al amor verdadero", FFH (1953), pp. 7-11, p. 10. Con las autoridades del lugar, E. González promovió un acto de confraternización entre la comunidad israelita de Madrid y el pueblo de Hervás, que tuvo lugar el 17 de octubre de 1971.

68 M. MUÑOZ DE SAN PEDRO, Extremadura (la tierra en la que nacian los dioses), pp. $121-124$. 
brió un documento en el archivo catedralicio de Plasencia que le permitió identificar el "Machón" con la lápida sepulcral de Alonso Sánchez - mandada tallar en 1395-, añadiendo la injustificada e injustificable apostilla de que fue probablemente "ubicada en el puente por los judíos" ${ }^{69}$. Que incluso en un trabajo de documentación histórica con base de archivo como éste se aprecie la influencia y las interferencias de los falseadores modernos del pasado judío de Hervás - la mención judía de M. Sánchez-Mora está tomada indudablemente de los fantásticos escritos de E. González - ayuda a entender la credulidad y la permeabilidad de la tradición popular a los mismos estímulos, que han persuadido a muchos habitantes a creer que la efigie fue instalada en el antepecho del puente como recordatorio de la conversión voluntaria de los judíos de Hervás al cristianismo y de la reconciliación de las dos comunidades religiosas.

\section{El ADAGIO ANTISEMITA "EN HERVÁS, JUdíOS LOS MÁS"}

En el momento de decretarse la expulsión de los judíos hay documentación de que vivían en Hervás 45 ¿personas o familias? hebreas, de las cuales al menos 13 se exiliaron, si bien algunos tornaron en 1494 . Cuatro decenios después se puede comprobar por el censo de 1534 que en Hervás había empadronados 178 "vecinos pecheros", de lo que se puede deducir que la mayoría - una vez restado un máximo de 45 conversos- eran cristianos viejos ${ }^{70}$. La ascendente expansión demográfica de los conversos frente a los cristianos viejos, unida a la conflictividad socio-política suscitada en la población por causa de los estatutos de limpieza de sangre y el control económico del municipio por la comunidad judeoconversa, originó que empezase a correr a fines del siglo XVII el dicterio antisemita "en Hervás, judíos los más", entendiendo por ajudíon a los conversos, aunque debemos argüir que no lo hallamos documentado hasta finales del siglo XIX. Es concretamente a partir de 1886 cuando numerosos colectores han empezado a recogerlo y di-

69 M. SÁNCHEZ MORA, «Un hombre que honra a un pueblo", FFH (1962), pp. 11-25, p. 25. El autor no cita las fuentes, pero lo tomó del Archivo de la Catedral de Plasencia. Testamentos, leg. 14, núm. 29. En realidad, la idea de asociar la figura del "Machón" con la estatua yacente de Alonso Sánchez es de M. SAYáns CaSTAÑos; cfr. Sepulcro y escultura de Santa María de Plasencia (Plasencia, 1984), p. 90.

70 T. GONZÁlez, Censo de población de las provincias y partidos de la Corona de Castilla en el s. XVI (Madrid, 1829), p. 100. 
fundirlo de manera continuada ${ }^{71}$, expandiendo la idea de que hubo en Hervás una predominante comunidad hebrea en el siglo XV. Y en la década de los setenta de la presente centuria, con el soplo de los vientos turísticos que recorrían la Península, la localidad ha dado un considerable vuelco ideológico a la cuestión y reciclado el viejo vituperio antijudaico en un proverbio filosemita, reconvertido en una de las principales señas de identidad comunitaria. De forma que, si antaño para los hervasenses ese proverbio pudo suponer un baldón, hoy es, en cambio, uno de los más apreciados blasones de la herencia hebraica de la que, incluso, presumen.

\section{LA INVENCIÓN DEL EXILIO JUDÍO}

Existe documentación de archivo que revela la identidad de los judíos que se exiliaron de Hervás en 1492: Nehoray Salvadiel, Bella, Mose Escapa, Ça Cohen, la mujer de Vidales, los hijos de Jaco Hamiz, Mose y Yuçe Zarco, los hijos de la Harona, Mose Orabuena, Bellida la Rica, Jaco de Ruego y rabí Simuel. Es muy probable que también lo hicieran otros judíos no identificados en las escrituras. Los desterrados fueron conducidos hasta la frontera portuguesa por Francisco Sayçilero ${ }^{72}$, y en 1494 tornaron algunos exiliados, entre ellos, rabí Simuel. Hasta aquí llega la evidencia documental. Pero la imaginación de muchos recreadores del pasado judío de Hervás llega mucho más allá. J. Rodríguez Trinidad envió a los judíos exiliados a Murcia ${ }^{73}$, en tanto que M. ${ }^{a}$ Teresa Rodríguez hasta concretó una cifra numérica, apuntando que:

71 Aparece por primera vez en A. Manzano. Véase V. PAREDES, "Hervás", pp. 97-106, p. 99; G. Vergara, "Apodos que se aplican en algunas localidades", Boletin de la Real Sociedad Geográfica, XV (1918), pp. 331-345, p. 338; P. HuRTADO, Castillos, Torres y Casa Fuertes de la provincia de Cáceres (Cáceres, 1927), 2." ed., pp. 284-285; F. CANTERA, "Informe sobre solicitud...", p. 389; V. CHAMORRO, Guía secreta de Extremadura, p. 27; J. García Atienza, Guía judia de España, p. 174; y Caminos de Sefarad, p. 216; $\mathrm{R}$ CARNICER, Las Américas peninsulares. Viaje por Extremadura, p. 58; C. GARCía MARTínez, Béjar en su Historia (Salamanca, 1991), II, p. 33. G. R AMECHAZurra situó la aljama de Hervás entre las seis más importantes de la Península. Ver "Sefarad, la segunda patria de los judíos", El País (Madrid, 26 de enero de 1986), p. 20; A. VÁzQuez, "Saludo del presidente de la Asamblea de Extremadura", $F F H$ (1993) [pp. 7-8, p. 8]. A. Martín LÁzaro cifró en 300 los judíos de Hervás. Cfr. "Geografía histórica de Béjar", Béjar en Madrid, VIII (Madrid, 1 de junio de 1924), p. 6, cuya conclusión recogió C. García Martínez, Béjar en su Historia (Salamanca, 1993), III, p. 84.

72 M. DE HeRvás, «Los judíos de Hervás", pp. 58-70, pp. 68-69.

73 Cfr. J. JimÉneZ, «Hervás. Tierra del agua...», FFH (1956), pp. 15-33, p. 29. 
de la judería hervasense salieron unas 67 familias, cuyos nombres son los siguientes: Mosé Salvadiel, Mosé Zarco, Zuce Zarco, Yusé Molsó, Don Asar [...] la salida de Castilla la realizaron por el punto fronterizo más cercano, es decir, por Portugal [...] los judíos hervasíes [sic] marcharon a Amsterdam.

"Información" repetida por otros agentes transmisores ${ }^{74}$. Yo mismo aventuré en su día que los 67 [sic] judeohervasenses se exiliaron en Amsterdam, Tánger, Venecia y Turquía ${ }^{75}$, mientras que V. Chamorro les alojó en Gre$\mathrm{cia}^{76}$, P. Alonso y A. Gil en el continente africano, Portugal e Italia ${ }^{77}$ y A. Roa y M. Gómez en Turquía ${ }^{78}$.

\section{LA LEYENDA DE LA HOSTIA CONSAGRADA}

Existe constancia documental en el Archivo General de Simancas de que, en 1506, se acusó al cristiano viejo Juan Sastre - aunque el nombre parece de cristiano nuevo, la documentación lo señala como "viejo" - de profanar la sagrada forma de la iglesia de Aldeanueva del Camino con intención de venderla a unos judeoconversos. Por la comarca circuló el rumor de que, mientras los conversos de Aldeanueva del Camino y de Hervás ultrajaron la hostia consagrada sumergiéndola en un caldero de agua hirviendo, en la iglesia de Hervás sudó milagrosamente un "crucifijo pintado en el altar mayor.. En un documento de fecha posterior conservado en el Archivo del Monasterio de Guadalupe se da una versión distinta de los hechos, trasladando la fecha del suceso a 1519, atribuyendo la sudoración a las imágenes de la Quinta Angustia, San Juan, la Magdalena y otros santos que aún no se habían fabricado en 1506, e imputando a los judíos la autoría del sacrilegio eucarístico. Detalle este último que fue, por supuesto, el que más raíces echó en la mentalidad popular y en la tradición religiosa hervasense ${ }^{79}$.

La leyenda de la profanación de la hostia consagrada - la única parte de la fábula que puede tener, si es que tiene, algunos visos de historici-

74 M. ${ }^{a}$ RodríguEZ, "Reseña histórica de la Villa de Hervás", FFH (1974), pp. 27-33, p. 29. Los mismos datos fueron retomados, sin citar fuentes, en M. Martín CastellaNO, "Hervás, resumen de su historia", FFH (1988), p. 13.

75 M. MARTín, "Barrio judío", FFH (1983), pp. 69-72, p. 70.

76 V. CHAMORRO, Guía secreta de Extremadura, pp. 26-27.

77 P. AlONSO y A. GIL, La memoria de las aljamas. Paseos por las juderías españolas, p. 95.

78 A. ROA y M. GÓMEZ, Hervás, imágenes de su bistoria, p. 28.

79 Véase M. DE HERVÁs, «Calumnias antisemitas cacereñas", Actas de las Jornadas Extremeñas de Estudios Judaicos (Badajoz, 1996), pp. 205-248, pp. 230-248. 
dad - puede ser ejemplo revelador de la capacidad de cambio de la tradición por impulso de sus manipuladores. La tradición oral de principios del siglo XVIII tenía presente la versión del milagro atribuído a la virgen de las Angustias en 1519, pero la cuestión empezó a entrar en una dimensión distinta a partir de 1916, cuando el deán de Plasencia, E. Escobar Prieto, resumió el texto de Guadalupe de esta manera:

en la noche del 24 de abril de 1519, un vecino de Villoria [...] robó de la iglesia de Santa María de Aldeanueva del Camino las sagradas formas y las llevó a Hervás, entregándolas a un judío. Éste las volvió a llevar a Aldeanueva del Camino, donde, en unión de tres cristianos nuevos, cometieron con ellas los más horrendos sacrilegios ${ }^{80}$.

El franciscano C. García Villacampa publicó íntegramente el libelo guadalupense en $1924^{81}$, dando pie a que varios divulgadores hervasenses lo reprodujesen, retocasen y ampliasen fantásticamente desde mediados del siglo $\mathrm{xx}^{82}$. Por razones desconocidas, J. Sánchez Matas desplazó la fecha del prodigio eucarístico a $1526^{83}$, y en la década de los sesenta el periodista Cacho-Balda, probablemente informado por algún natural del pueblo, publicó que los judíos de Hervás escondieron las sagradas formas en:

un muladar del barrio judío. Allí también se obró un milagro, pues en el punto indicado, un resplandor extraño señalaba el enterramiento de las hostias. El sacerdote arrodillado recobró completamente intactas todas ellas. Y es entonces cuando la Virgen [...] cesó de llorar ${ }^{84}$.

80 E. Escobar Prieto, El Monasterio de Guadalupe, I, núm. 9 (1 de noviembre de 1916), pp. 194-196, p. 196. No concreta el legajo de donde tomó su información.

81 C. GaRCía VillaCAmPa, Grandezas de Guadalupe (Madrid, 1924), pp. 413-417. El fraile publicó íntegramente el manuscrito del Archivo del Monasterio de Guadalupe. Tampoco citó la signatura.

82 A. SÁNCHEZ HERRERo, "Si a la Feria vienes...", FFH (1947) [pp. 13-14]; J. RODRíGUEZ TRINIDAD, "Asombroso y memorable prodigio Eucarístico acaecido en Hervás en 1519", FFH (1948) [pp. 9-13]. J. Rodríguez Trinidad informó del suceso a F. CANTERA Burgos, Sinagogas españolas, p. 228. V. GINARTE, Hervás: su bistoria, su tierra, su gente, pp. 25-29.

83 J. SÁNCHEZ MATAS, "Recopilación de datos sobre la historia de Hervás», $F F H$ (1957), pp. 27-35, p. 31; de donde lo tomó E. GonZÁleZ, "Amor sin venda", FFH (1959), pp. 7-11, p. 11.

84 CACHO Balda, Arriba (Madrid, 16 de junio de 1960) p. 18; reproducido en $F F H$ (1960), p. 31; A. MUÑ̃Z DE LA PEÑA, "El Barrio Judío de Hervás", FFH (1969), pp. 25-29, p. 29. 
Dos decenios después, J. Sendín ${ }^{85}$ agregó nuevos elementos de su cosecha a la fábula. Así, se inventó la judería de Villorga [Villoria] y la figura del rabino Juan Blanco; al cristiano viejo Juan Sastre le hizo judío; la casa de Nicolás Nieto, que estaba en Hervás, la mudó a Aldeanueva del Camino; e imputó el milagro eucarístico a Nuestra Señora de las Aguas Vivas o de la Asunción; de tal suerte que su versión se ha impuesto sobre las demás y está siendo aceptada y transmitida por la tradición popular como si fuese la auténticamente genuina ${ }^{86}$.

FÁBULAS SOBRE SUPUESTOS NOMBRES, COSTUMBRES Y VESTIGIOS DEL PASADO JUDÍO DE HERVÁS

Al investigar en los libros de natalicios de la iglesia parroquial de Santa María de Hervás, se puede comprobar que cuando los judíos se convirtieron forzosamente al cristianismo utilizaron $-\mathrm{y}$ pusieron a sus descendientes- nombres cristianos sustitutos de los hebreos, prohibidos por la Inquisición ${ }^{87}$. Fue después de la abolición definitiva del Santo Oficio en el siglo XIX cuando los nombres con resonancias hebreas vuelven a normalizarse, igual que sucedió en muchos otros lugares de España. El desconocimiento de la historia del judaísmo local y nacional ha contribuido a divulgar, sin embargo, la teoría de que los nombres de resonancias hebreas de Hervás son una tradición que se remonta directa e ininterrumpidamente hasta el Medievo ${ }^{88}$.

Asimismo, sobre el infundio de que los hervasenses han mantenido a lo largo de los últimos cinco siglos buena parte de las costumbres o de

85 J. SENDín, "Lágrimas de Viernes Santo. Hervás", Tradiciones Extremeñas (León, 1990), pp. 117-125.

86 P. Alonso y A. GIL, La memoria de las aljamas. Paseo por las juderías españolas, pp. 95-96. A. T. B., "Historia", El Compadre Noticiero, III, núm. 30 (septiembre de 1994), pp. 4-5, describe a los judíos de Hervás como consumados especialistas en actos irreverentes contra la religión cristiana, cargando además en su cuenta otro supuesto apedreamiento sacrílego que nadie antes les había atribuido a ellos: "en 1448 los judíos de Hervás profanaron la cruz bendita en Casar de Palomero".

87 En 1785 se bautizó en Hervás Luis Salomón; cfr. Archivo Parroquial de Hervás. Libro de bautismo núm. 8 (1781-1792), f. 114; y en 1815, Francisco Isaac; cfr. $A P H$. Libro de bautismo núm. 10 (1811-1825), f. 112.

88 E GonZÁlez, "Amor sin venda", FFH (1959), pp. 7-11, p. 9; A. MUÑOZ DE LA PEÑA, "El barrio judío de Hervás", FFH (1969), pp. 25-29, p. 25; V. CHAMORRO, Guía secreta de Extremadura, p. 23; y Por Cáceres de trecho en trecho, p. 14; L. MEDINA García, «Hervás, monumento a la tradicionalidad judía", pp. 28-41, p. 32. 
la identidad hebraica de sus antepasados, diversos autores elaboraron ciertas tesis con resabios artificiosos que no llegaron, sin embargo, a ser aceptadas en el repertorio popular. Como sucede con el juego infantil de supuesta procedencia judía bỉblica que creyó haber rescatado E. González en 1959:

que consiste en lo siguiente: un niño puesto de espalda a la pared se tapa los ojos con una mano y apoyando la otra sobre la espalda, con la palma vuelta hacia arriba, espera. Uno de los compañeros, se acerca sigilosamente pellizcándole y retirándose rápidamente al lugar que antes ocupaba, pregunta: "¿Quién te picó?". El niño que estaba vuelto de espaldas contesta: "El Rabín y entonces responden: "Tráemelo de la punta de la nariz", es decir, que adivine quien fue. Fácilmente vemos en este humillante juego, la relación que tiene con aquel otro en que los sayones judíos insultaban a Jesús, después de golpearle, diciéndole: "QQuién te hirió?. Antiguamente también había una costumbre típicamente judía, durante la comida en las bodas, y que consistía en tirar trocitos de pan a los comensales distraídos o tímidos. Es lo mismo que hacen los judíos en sus bodas cuando asiste a ellas algún cristiano para burlarse de él, sin que éste pueda interpretarlo como desprecio ${ }^{89}$.

Otra costumbre erróneamente asociada a una hipotética tradición judía de Hervás es la del espiguijo, o dote económica que los familiares y amigos entregan el día de la boda cristiana a los recién casados ${ }^{90}$. Asimismo, diversos autores han creído, y publicado en sus crónicas periodísticas -que más parecen ejercicios de surrealismo culinario-, que los cristianos nuevos de Hervás mantuvieron durante siglos las prescripciones alimentarias judaicas. Hay quien ha escrito que los hervasenses han disfrazado las denominaciones de ciertas legumbres con resonancias hebreas, de tal forma que a las judías blancas las llaman "pipas" y a las judías verdes "frejones", haciéndose eco igualmente de la fantástica creencia de que los cristianos viejos "para probar su despego a la ley mosaica, enviaban dádivas tras la matanza [a los conversos] compuesta de sangre, hígado y otras vísceras - todo repulsivo para un verdadero judío-, que aquí se conocen con el nombre de "freje" ${ }^{91}$. No menos original disparate gastronómico es el relatado por M. Domínguez Rey, quien dice haber comido "pollo a

89 E. GoNZÁlEZ, «Amor sin venda", FFH (1959), pp. 7-11, p. 9; y "Adivina... ¿Quién te hirió?n, Mis versos de ayer y hoy, pp. 209-210.

90 V. ChAMORRO, Guía secreta de Extremadura, p. 23, recogido por J. M. PEDROSA, "Visión de lo judío en la cultura popular extremeña", pp. 249-283, p. 269.

91 R. SERRA, «Hervás", Periplo, XIII, núm. 76 (1987), pp. 70-79, p. 78; información suministrada por $\mathrm{N}$. Duarte. Se refiere a la sopa de freje, un guiso elaborado con sangre de cerdo, pan y comino. N. CARRASCO ARAUZ, "Esmeralda de agua", FFH (1962), pp. $51-59$, p. 51. 
la xudiega de Hervás aderezado con cebolla frita y pimienta" ${ }^{92}$, o el que refiere como típicamente judío ael hornazo, pan sin levadura relleno de huevo al que se incorporaría mas tarde jamón, lomo y chorizo" ${ }^{93}$.

Para poner punto final a este peculiar menú de disparates gastronómicos, podemos recordar que la palabra "marrano", con que se designó peyorativamente a los judíos conversos que se quedaron en España y que a menudo seguían practicando en secreto la religión de sus antepasados ("marrar", "errar" es una de las etimologías con que algunos han querido explicar la voz marrano), ha sido entendida de forma muy particular por algunos comentaristas del marranismo hervasense, que opinan que para evitar ser expulsados, muchos judíos se hicieron marranos: fingieron la conversión comiendo carne de cerdo. Aún más: como el cerdo es un alimento impuro para el judío, se piensa —quizás por deferencia hacia el paisano converso- que "de los muchos nombres del puerco, todos menos 'marrano' se usan en Hervás" ${ }^{94}$.

Otro desatino terminológico en que incurren numerosos comentaristas de la herencia judía de Hervás - y muchas personas e incluso investigadores al referirse al judaísmo hispánico y mediterráneo en general- se refiere al término "sefardín. Sefardíes son los descendientes de los judíos españoles expulsados de la Península en el siglo XV. A los judíos que habitaron en la Península antes de la expulsión se les conoce con el nombre de judíos españoles, y a su cultura, cuando se expresa en hebreo, hebraicoespañola o hispanohebrea. Tampoco deben ser denominados sefardíes los judíos españoles que abrazaron forzosamente el cristianismo (judeoconversos, cristianos nuevos, marranos) y judaizaron en secreto (criptojudíos, judaizantes) ${ }^{95}$. En Hervás se aplica incorrectamente el vocablo sefardí al judío hispano medieval, error surgido en varias crónicas líricas y periodísticas a mediados del siglo $\mathrm{xx}$, perpetuado y asimilado finalmente por la población ${ }^{96}$, e incluso por las instituciones extremeñas,

92 M. Domínguez, "El jardín de Extremadura”, $F F H$ (1981) [pp. 31-33, p. 31].

93 L. SÁNCHEZ BARDÓN, "La ruta de la Plata", Viajar, núm. 128 (1996), p. 9. Véase mi artículo "De la gastronomía hebrea de Hervás», Hoy (Badajoz, 18 de mayo de 1996), p. 28; véase nota 90 .

94 R. SERRA, "Hervás", Periplo, XIII, pp. 70-79, p. 76.

95 P. DÍAZ-MÁs, Los sefardies. Historia, Lengua y Cultura (Barcelona, 1986), pp. 23-25.

96 E. GonZÁlez, "Hervás. Canto al amor verdadero", $F F H$ (1953), pp. 7-11, pp. 7 y 9; "Advenimiento", FFH (1960), p. 41; "Nuevamente amanece en el Valle del Ambroz", $F F H$ (1970), p. 41; "Amadas cosas de Hervás", FFH (1986) [p. 19]; V. MONTES, «Poblamiento", FFH (1965), pp. 29-33, p. 29; M. MARTíN, "Barrio judío", FFH (1983), pp. 69-72, p. 70; E. GONZÁlEZ, Er cante $y$ otros escritos. Misa del Cante Grande 
hasta el extremo de que se ha creado un proyecto urbanístico encaminado a recuperar el barrio "sefardita" (PEPYRCABS); y además, está prevista la creación del Centro Cultural de Estudios Sefarditas, con un espacio destinado a "museo". El carrusel de disparates pseudosefardíes ha salpicado también a determinados villancicos, hasta el extremo de que M. Álvarez Encinas considera que algunos cánticos navideños hervasenses son de origen sefardí ${ }^{97}$.

Para perpetuar desatinos y prejuicios como los que hemos ido señalando, en nuestra región - y en otras comunidades autónomas- se halla muy extendida la creencia que atribuye a los hervasenses ciertos caracteres fisonómicos hebreos, en patente contradicción con la antropología moderna, que ha descartado que el pueblo judío constituya una unidad con rasgos étnicos diferenciados. Muy difícil es, sin embargo, convencer al pueblo, acostumbrado a creer en grandes tópicos étnico-culturales, de que los hervasenses no tienen rasgos fisonómicos supuestamente judaicos, como un exagerado apéndice nasal —afilado y picudo-, tez morena y "ojos color de cuervo" ${ }^{98}$. El desatino se revela en toda su cruda dimensión cuando muchos de los visitantes del "barrio judío" achacan al vecindario una apariencia judía característica, aún cuando alguno de los señalados como “judíos" ni siquiera son ni tienen ascendencia hervasense.

De la misma manera, la arquitectura popular tampoco se ha librado de falsas generalizaciones de este tipo. La lobreguez y austeridad de las casas entramadas de madera de castaño y sus estrechos ventanucos, los zaguanes con los portales pintados de azul y las callejuelas retorcidas que parecen garabatos trazados en el suelo del barrio medieval ${ }^{99}$, se han asociado innumerables veces a una imaginaria tradición arquitectónica judía que ha llevado al disparatado extremo de que, en la década de los ochenta del presente siglo, alguien haya alumbrado la tesis que atribuía la arquitectura popular entramada al pueblo hebreo. Cuando lo que tenemos es un barrio histórico exponente de una arquitectura popular caracterizada por el sistema de tramazón de madera, relleno de adobe o ladrillo, que

(Plasencia, 1989), p. 8; P. VAQUero PÉREZ, "Desde el aula de medio ambiente en Hervás", FFH (1990), [pp. 59-61, p. 59].

97 M. Álvarez Encinas, "La Nochebuena en Hervás", FFH (1995) [p. 69].

98 E. GonZÁlez, "Canto al amor verdadero", $F F H$ (1953), pp. 7-10, p. 8; N. SÁNCHEZ MORALES, "Hervás: temas y variaciones", FFH (1970), pp. 7-11, p. 9; V. CHAMORRO, Guía secreta de Extremadura, p. 23.

99 V. PAREDES, «Hervás", pp. 97-106, p. 105; A. SÁnCHEZ Herrero, «Si a la Feria vienes..., FFH (1947) [pp. 13-14, p. 14]; D. SALAS, "Hervás, diversidad y síntesis", FFH (1962), pp. 27-39, p. 39; J. L Álvarez, «La judería de Hervás”, FFH (1975), pp. 9-13, p. 13. 
también se da en otras comarcas. A propósito de prejuicios y disparates arquitectónicos, baste poner el ejemplo del erudito V. Paredes, quien, parafraseando al historiador Bernáldez, dijo que las casas de la judería de Hervás “olían a judío como ellos, porque sus alimentos sin grasas les daba un olor repugnante" ${ }^{100}$; o el de aquel que imaginó a los judeohervasenses en una actitud burlesca acechando desde sus casas a los visitantes y haciéndoles "zirigoncias" 101.

Como últimos botones de muestra del legendario pseudojudío de Hervás, de la capacidad manipuladora de sus creadores y de su influencia distorsionadora sobre las señas de identidad y la ideología comunitarias, se puede señalar que en 1952 el hervasense Lorencio detectó "en el Collado, por las enfermerías, en casa que todavía sostiene su balconaje, [unas] columnas finas adornadas con motivos orientales - de traza judaica— $\longrightarrow$ 102. Lo cual nos obliga a hacer arduos esfuerzos de comprensión, porque la construcción de las casas data del siglo xviII. No menos imaginativas fueron las conclusiones de A. Calzado, J. Santos y D. Vargas, quienes, seducidos por el descubrimiento de ocho monedas que tenían las inscripciones "1274", "1298" y la estrella de David, aventuraron: "estas monedas pertenecerían al dinero de uso interno de un grupo cristiano-judío-musulmán; hombres de las tres creencias en torno a un trabajo común, la Cábala [j]!, por ejemplo" ${ }^{103}$. Asombrosas conclusiones que amplió F. M. Bejarano Neila cuando señaló que "por si hubiera alguna duda del origen judío de estas monedas, hemos de pensar que como las monedas se acuñaron dentro del reinado de Alfonso X el Sabio [1252-84], y que este rey fue un gran protector del pueblo judío, llegando incluso a construir sinagogas, ipor qué no iba a dejarles también acuñar monedas en las comunidades judías más importantes?” ${ }^{104}$. Algunos meses después, los mismos A. Calzado, J. Santos y D. Vargas desmintieron sus conjeturas al descubrir que las susodichas monedas correspondían al año 1274 y 1298 de la Hégira musulmana, esto es 1875 y 1901 de la era cristiana ${ }^{105}$, y procedían probablemente de las colonias españolas del Norte de África.

100 V. PAREdES, "Hervás", pp. 97-106, p. 105.

101 A. García García, "A Hervás, mi partido judicial», FFH (1977), pp. 17-21, p. 19.

102 LORENCIO, «Leyendas de la villa. La casa del miedo", $F F H$ (1952), p. 33; y $F F H$ (1994) [p. 37].

103 D. VARgas, A. CAlzado y J. SANTOS, "¿Monedas judías en Hervás?", El Compadre Noticiero, I, núm. 2 (mayo de 1992) [p. 3].

104 M. BEJARANO, "Monedas judías del siglo XIII, $F F H$ (1992) [p. 77].

105 D. VARgas, A. CAlzado y J. SANTOS, "No son judías", El Compadre Noticiero, I, núm. 4 (julio de 1992) [p. 3]. 


\section{CONCLUSIONES}

Finalizado el análisis del corpus de leyendas y creencias sobre el pasado judío de Hervás, resulta que la más antigua leyenda documentada - la del ultraje de la hostia consagrada - se remonta al siglo XviII -aunque enlaza con sucesos atribuidos a comienzos del siglo XVI a conversos de fuera de Hervás-. El resto de las fábulas "judías" germinaron a la sombra del movimiento romántico-costumbrista extremeño de finales del siglo XIX, y cobraron impulso sobre todo a partir de la segunda mitad del siglo $\mathrm{xx}$, al entrar en un circuito de falsificaciones y deformaciones creadas por divulgadores y eruditos carentes de conocimientos y método historiográfico, alentados por intereses turísticos y por instituciones que han colaborado activamente - por esos mismos intereses - en la acuñación de una determinada imagen de "marca judía" que tiene muy poco que ver con el pasado histórico y cultural de Hervás.

La identificación de una comunidad con arquetipos históricos y culturales heredados del pasado y moldeadores en cierto modo del presente es una constante en el desarrollo de todas las sociedades, que fluctúan entre dos polos opuestos pero complementarios en su línea de acción ideologizadora de la comunidad: la evolución histórica y cultural ininterrumpida e interna del pueblo, asociada a su más pura tradición folclórica; y la acción puntual, intermitente y externa, ligada a la tradición escolar o culta, de grupos de poder cultural o político que interfieren su curso normal y encauzan por vías espúreas e interesadas el discurrir de la tradición popular. Cuando el equilibrio natural entre ambos polos se rompe y el restringido grupo de activistas "cultos" y políticos se inmiscuye en tal cadena con fuerza suficiente como para suplantar la historia real por un pasado inventado por ellos, que se convierte en una de las señas de identidad básicas del presente, el pueblo pierde la oportunidad de conocerse a sí mismo, y se queda sólo con el espejismo de un pasado falso e irreal, aunque en los tiempos que corren se pueda rentabilizar turística y económicamente. Hervás tuvo, sin lugar a dudas, un innegable pasado judío lleno de interés histórico y cultural. Pero conocerlo exige una minuciosa, lenta, responsable y sacrificada labor de investigación en archivos y bibliotecas y una exposición rigurosa y científica de sus resultados. No una carrera de deformaciones, falsedades y exageraciones que, al final, se han convertido en los más peligrosos enemigos de la historia y la identidad de un pueblo que cuenta con un legado y una tradición lo suficientemente valiosos e interesantes como para no necesitar ni me- 
recer que le inventen sucedáneos tan lamentables como los que se han acumulado sobre él ${ }^{106}$.

\section{MARCIANO DE HERVÁS}

La falsificación de la tradición histórico-cultural hebrea de Hervás, alumbrada por ciertos eruditos locales a la sombra del movimiento romántico-costumbrista extremeño de fines del siglo XIX, y asumida por la inventiva popular, ha fraguado en la sociedad unas fingidas señas de identidad «judía", proceso que podemos considerar como la invención de una tradición.

The forgery of a Hebrew historico-political tradition in Hervas, initiated by some local erudites of the late 19th century in the wake of the romantic movement in Estremadura in the literature of manners, and later adopted by the general population, has caused the diffusion in the region of some false characteristics of "Jewish" identity -a process that can be regarded as the invention of a tradition.

106 Agradezco a José Manuel Pedrosa las indicaciones ofrecidas para la redacción de este artículo. 